\title{
Protecting children's rights under the ECHR: the role of positive obligations
}

\author{
Dr URSULA KILKelly*
}

Faculty of Law, University College Cork

\begin{abstract}
Introduction
$\mathrm{T}$ The European Convention on Human Rights (ECHR) contains few express references to children and so its potential to protect children's rights is not immediately apparent from its text. In fact, the ECHR mentions children only twice, although other ECHR provisions - notably Article 8 on the right to respect for private and family life - have special relevance to children. It is in these and other less likely areas that the Convention's potential to protect the rights of children has come to be realised. This has been made possible by access to the right of individual petition by children and their representatives and has led to an increasing number of applications before the European Court of Human Rights (ECtHR). ${ }^{1}$ A number of interpretive approaches have been instrumental in the development of ECHR case law in children's cases, including the development of procedural obligations ${ }^{2}$ and the emphasis on effective rights protection. ${ }^{3}$ The Court has also sought to rely, increasingly, on other children's rights instruments, notably the Convention on the Rights of the Child (CRC), in order to ensure that its judgments reflect current standards in children's rights. However, as this paper will show, it is the Court's "positive obligations" approach that has underpinned ECtHR case law in the development of its children's rights jurisprudence, allowing it to make a genuinely unique contribution to international children's rights standards. Accordingly, the aim of this paper is to explore the contribution made by the positive obligations approach to the interpretation of the ECHR in cases involving children against the backdrop of the CRC. In particular, it seeks to explore the role of this approach in securing children's rights under the ECHR and considers the contribution that the Court's positive obligations jurisprudence has made to the protection of children's rights. The article begins with an introduction to the CRC, the principal international standard-setting instrument in this area. It then goes on to outline the relevance and significance of the ECHR to children before outlining three areas in
\end{abstract}

* Senior Lecturer and Co-Director of the Centre for Criminal Justice and Human Rights at the Faculty of Law, University College Cork.

1 See, generally, U Kilkelly, The Child and the ECHR (Aldershot: Ashgate 1999). See also U Kilkelly, "Children's rights; a European perspective" (2004) 4 Judicial Studies Institute Journal 68-95 and J Fortin, "Rights brought home for children" (1999) 62 MLR 350.

2 See D Harris, M O'Boyle, E Bayts and C Buckley, Harris, O'Boyle and Warbrick: Law of the European Convention on Human Rights 2nd edn (Oxford: OUP 2009), pp. 18-21.

3 See Kilkelly, The Child, n. 1 above. 
which the positive obligations approach has played a central role in the determination of applications concerning the treatment of children. It concludes with an outline of what further potential the positive obligations approach might offer in the advancement of children's rights under the ECHR.

\section{The Convention on the Rights of the Child}

The CRC was the first comprehensive, internationally binding treaty to give full recognition to the individual rights of children. ${ }^{4}$ Its widespread ratification - by all UN members except the USA and Somalia - suggests that it is consistent with a strong level of international consensus on the way children should be treated in a wide variety of areas and circumstances. ${ }^{5}$ The Convention is widely regarded as the "touchstone for children's rights throughout the world" 6 and its particular merits include its breadth and the extent of its detailed provision for the autonomous rights of children. ${ }^{7}$ Its comprehensive nature means that the CRC contains standards applicable to all areas of the child's life including school (Articles 28 and 29) and the family (Articles 3, 5, 12 and 18), as well as in specific settings of alternative care (Article 20,21) and youth justice and detention (Articles 37 and 40), for example. It provides for children's well-being in a variety of contexts (Articles 6, 24, 27) and makes specific provision for children with disabilities (Article 23), children whose parents have separated (Articles 3, 9), children who have suffered abuse and exploitation (Articles 19, 30-4, 37) and refugee children (Articles 7, 8, 10). The Convention contains rights of general relevance (Articles 7 and 8 on identity), rights of special importance to children (Articles 18 on family support and 31 on the right to play, rest and leisure) and general human rights adapted to the specific needs of children (Articles 13 on freedom of expression, 14 on expression of religion and 17 on access to information). Since its adoption, the Convention has been usefully explained by the adoption by the United Nations Committee on the Rights of the Child of numerous General Comments on issues such as adolescent health and development, child rights in early childhood, corporal punishment and juvenile justice. ${ }^{8}$ The Convention's implementation is monitored by the United Nations Committee on the Rights of the Child and so the Convention's growing jurisprudence now includes hundreds of Concluding Observations which detail the extent to which each state party has implemented the Convention. ${ }^{?}$

Despite the monitoring work of the Committee on the Rights of the Child, the absence from the Convention of any mechanism to enforce its provisions has been the subject of

4 General Assembly Resolution 44/25, 20 November 1989.

5 For details of ratification of the Convention, see www.unhchr.org.

6 J Fortin, Children's Rights and the Developing Law 3rd edn (Cambridge: CUP 2009), p. 49.

7 See D McGoldrick, "The United Nations Convention on the Rights of the Child" (2001) 5 International Journal of Law and the Family 133; and U Kilkelly, "The best of both worlds for children's rights: interpreting the European Convention on Human Rights in the light of the UN Convention on the Rights of the Child" (2001) 23 Human Rights Quarterly 308.

8 CRC Committee, General Comment No 4, Adolescent Health and Development in the Context of the Convention on the Rights of the Child CRC/GC/2003/4, 1 July 2003; CRC Committee, General Comment No 7, Implementing Child Rights in Early Childhood CRC/C/GC/Rev. 7, 20 September 2006; CRC Committee, General Comment No 10, Children's Rights in Juvenile Justice CRC/C/GC/10, 25 April 2007; and CRC Committee, General Comment No 8, The Right of the Child to Protection from Corporal Punishment and Other Cruel or Degrading Forms of Punishment CRC/C/GC/8, 2007.

9 On the reporting process see U Kilkelly, "The UN Committee on the Rights of the Child: an evaluation in the light of recent UK experience” (1996) 8 Child and Family Law Quarterly 105. 
negative comment. ${ }^{10}$ There is no international court to adjudicate on children's rights issues and no body that children can petition to seek to have their CRC rights vindicated. Although international dialogue on the addition of a protocol to provide children with a right of individual petition has finally begun, ${ }^{11}$ it is important nonetheless to continue to explore alternative ways in which the Convention's potential to improve the treatment of children can be realised. The increasing use of the CRC in research to benchmark and monitor implementation of children's rights is an important development in this regard. ${ }^{12}$ However, its use in litigation is arguably a more strategic and immediate way to advance specific children's rights goals. ${ }^{13}$ To this end, use of the CRC in litigation at national and international levels is key and use of the Convention by the ECtHR illustrates very clearly what added value child-specific standards can bring to an already effective system of individual petition. ${ }^{14}$

\section{The ECHR and children}

In some respects, the ECHR could not be more different from the CRC. The ECHR, which came into force in 1953, is a regional instrument drafted by the Council of Europe as a response to the atrocities of the Second World War. ${ }^{15}$ Its scope is not comprehensive and it is defined largely by civil and political rights, such as the freedom from torture and the rights to life, fair trial and liberty. Without its supplementing protocols, the ECHR makes no reference to particularly vulnerable groups; its references to children are limited to just two provisions. ${ }^{16}$ Article 6 , the right to a fair trial, makes provision for the press and public to be excluded from all or part of a trial "where the interest of juveniles . . require", whereas Article 5(1)(d) makes provision for the detention of a "minor for the purpose of educational supervision and to bring a minor before the competent legal authority".17 There has been some case law under these provisions, notably concerning the child's right to participate effectively in criminal proceedings under Article $6,{ }^{18}$ and the detention of a

10 D Balton, "The Convention on the Rights of the Child: prospects for international enforcement" (1990) 12 Human Rights Quarterly 120; T Hammarberg, "The UN Convention on the Rights of the Child - and how to make it work" (1990) 12 Human Rights Quarterly 97; and D Fottrell, “One step forward or two steps sideways? Assessing the first decade of the Convention on the Rights of the Child” in D Fottrell (ed.), Revisiting Children's Rights 10 years of the UN Convention on the Rights of the Child (The Hague: Kluwer Law International 2000), p. 1.

11 Report of the Open-ended Working Group to Explore the Possibility of Elaborating an Optional Protocol to the Convention on the Rights of the Child to Provide a Communications Procedure, report by the Human Rights Council, UN Doc. A/HRC/13/43, 21 January 2010, available at www.ohchr.org.

12 U Kilkelly, “Operationalising children's rights: lessons from research" (2006) 4 Journal of Children's Services 35; and U Kilkelly and L Lundy, "Children's rights in action: using the Convention on the Rights of the Child as an auditing tool" (2006) 18 Child and Family Law Quarterly 331.

13 See P Geary, Children's Rights: A guide to strategic litigation (London: Children's Rights Information Network 2009).

14 See U Kilkelly, "The best of both worlds", see n. 7 above; and U Kilkelly, "Effective protection of children's rights in family cases: an international approach" (2002) 12 Transnational Law \& Contemporary Problems 336.

15 See Harris et al., Law of the European Convention, n. 2 above, p. 1.

16 In addition, Article 2 of Protocol 1 guarantees the right to education and Article 5 of Protocol 5 recognises parental equality and the role of the best interests of the child in the exercise of parental responsibility. No other provisions give express protection to children's substantive rights.

17 See U Kilkelly, "The Human Rights Act: implications for the detention and trial of young people" (2000) 51 NILQ 466.

18 See e.g. T v UK (1999) 30 EHRR 121 and SC v UK (2005) 40 EHRR 226. See, further, U Kilkelly, "Youth courts and children's rights: the Irish experience" (2008) 8 Youth Justice 39. 
child in the exercise by the state of parental authority under Article 5, for example. ${ }^{19}$ However, due mainly to the strict terms of these provisions, the scope of this jurisprudence has been limited in nature. Other, more generously worded provisions have provided the Court with greater flexibility and so, ironically, those provisions that make no reference to children have provided greater potential to have children's rights protected. There are two key provisions here. The first and most important provision is Article 8, which guarantees the right to respect for private and family life. The second, increasingly important provision is Article 3, which recognises the right to freedom from torture, and inhuman and degrading treatment or punishment. Although these two provisions could not be more different in form - Article 3 is an absolute prohibition to which no exceptions are permitted whereas Article 8 sets out the right in the first paragraph while the permitted limitations are explained in paragraph 2 - as analysis of the case law below will show, the Court's approach to both provisions in children's cases has been remarkably similar. It is here that the positive obligations approach has been critical.

Article 8 is by far the most litigated provision from a child's perspective and its case law has touched on many areas of family law including adoption, child abduction, alternative care, custody and access, guardianship and identity issues. ${ }^{20}$ As the next two sections show, in the areas of family ties and custody and access, the positive obligations approach has been crucial in ensuring the application of these provisions to children's cases. Notwithstanding that the application of Article 3 to children's issues has been a more gradual process, the positive obligations approach has been similarly critical in articulating the relevance of this provision to children. In particular, as explained below, case law on Article 3 has played a key role in protecting children from physical punishment and abuse, including at the hands of their parents. The following sections explain this jurisprudence in more detail.

\section{Family ties}

One of the major contributions of the ECHR to children's rights and generally is its case law on the legal recognition of family ties. Established in the ground-breaking case of Marckx v Belgium in 1979,21 this line of case law has encouraged the promotion of a childcentred approach to the legal recognition of family relationships, underpinned by the positive obligation to respect family life. The Marckx case concerned the requirement under Belgian law that an unmarried mother had to take certain steps to have her bond with her daughter legally recognised. The applicants - mother and daughter - complained that this breached their rights to respect for family life under Article 8 taken alone and together with the non-discrimination provision under Article 14. In its judgment, the Court established that the tie between mother and daughter in this case amounted to "family life" within the meaning of Article 8 and in reaching this conclusion, the Court rejected that a distinction could be made between the so-called "legitimate" and the "illegitimate" family. 22 The next step for the Court was to consider what "respect" for this family life required. Here, the Court noted that "the object of the Article is essentially that of protecting the individual against arbitrary interference by the public authorities", ${ }^{23}$ but it went on to say that,

19 See Koniarska v UK App. No 33670/96, 12 October 2000 and DG v Ireland App. No 39474/98, 16 May 2002. See, further, U Kilkelly, "DG v Ireland: protecting the rights of children at risk: a lazy government and unruly courts” (2002) 24 Dublin University Law Journal 269.

20 See Kilkelly, The Child, n. 1 above, and, more generally, Fortin, Children's Rights, n. 6 above.

21 Marckx v Belgium (1979-80) 3 EHRR 230.

22 Ibid. para. 31.

23 Ibid. 
"nevertheless", Article 8 does not "merely compel the State to abstain from such interference. In addition to this primarily negative undertaking, there may be positive obligations inherent in an effective 'respect' for family life". ${ }^{24}$ According to the Court:

This means, amongst other things, that when the State determines in its domestic legal system the régime applicable to certain family ties such as those between an unmarried mother and her child, it must act in a manner calculated to allow those concerned to lead a normal family life. ${ }^{25}$

Respect for family life, in the Court's view, implies: "the existence in domestic law of legal safeguards that render possible as from the moment of birth the child's integration in his family". 26

Although the state has a "choice of means" in this regard, a law that "fails to satisfy this requirement" violates Article 8(1) "without there being any call to examine it under paragraph 2". ${ }^{27}$ Applying this principle to the applicants' situation under Belgian law, the ECtHR found that the requirement that the applicant mother had to choose between taking steps to ensure legal recognition with her daughter and being able fully to give or bequeath property to her was "not consonant with 'respect' for family life", rather it thwarted and impeded the normal development of such life. ${ }^{28}$ Significantly, the Court held that the legal situation in which the daughter, Alexandra, was placed also resulted in "a lack of respect for her family life" under Article $8 .{ }^{29}$ So, through its application of the "positive obligations" approach in the Marckx case, the ECtHR not only recognised the right to legal recognition of biological family ties as a part of respect for family life, it extended that approach to children as well as their parents. In doing so -10 years before the adoption of the CRC, which recognised the child's right to respect for his/her family ties for the first time - the Court could clearly be said to be ahead of its time. ${ }^{30}$ Indeed, it is arguable that in the Marckex decision the ECtHR went even further than the protection guaranteed by Articles 7 and 8 of the CRC, which protect the child's right to identity but do not specify what that means or how that right is to be realised. ${ }^{31}$

The Court continued with this emphasis on the child's legal status in the case of Johnston v Ireland in $1986 .{ }^{32}$ Here, the Court came to consider the legal status under Irish law of a child born to parents who were unable to marry because her father had been married before and at the time divorce was prohibited under the Irish Constitution. As a result of her "illegitimate" status, Nessa suffered numerous disadvantages (e.g. she could not be adopted by her parents, legitimated by their subsequent marriage, nor could her father be appointed her guardian), which her parents were unable to alleviate, and together with her parents all three applicants complained that this violated their rights under Article 8 of the ECHR. Although the Court had failed to find that the applicant parents' inability to marry violated

24 Marckx v Belgium (1979-80) 3 EHRR 230.

25 Ibid.

26 Ibid.

27 Ibid.

28 Ibid. para. 36.

29 Ibid. para. 37.

30 Moreover, the Court drew inspiration here from the Council of Europe Convention on the Legal Status of Children born out of Wedlock, which was adopted in 1975 but had not yet entered in force at the time of the Marckx judgment. Ibid. para. 41.

31 See further S Besson, "Enforcing the child's right to know her origins: contrasting approaches under the Convention on the Rights of the Child and the European Convention on Human Rights" (2007) 21 IJLP \& F 137.

32 Johnston $\mathrm{v}$ Ireland (1986) 9 EHRR 203. 
their ECHR rights, the Court agreed that the daughter's status under Irish law raised a serious issue under Article 8.

The Court began by finding that all three applicants enjoyed "family life" within the meaning of Article 8 notwithstanding that the parents were not married. ${ }^{33}$ It then considered whether "respect for family life" imposed a positive obligation on the state to improve the child's legal situation. ${ }^{34}$ In short, the Court held that it did and, in reaching this conclusion, it made a distinction between the impact of Irish law on her parents (which was not incompatible with Article 8) and on the child (which was). ${ }^{35}$ In its judgment, the Court reiterated the Marckx principle that "respect' for family life . . implies an obligation for the State to act in a manner calculated to allow these ties to develop normally" ${ }^{36}$ It then went on to find that:

in the present case the normal development of the natural family ties between the first and second applicants and their daughter requires ... that she should be placed, legally and socially, in a position akin to that of a legitimate child. ${ }^{37}$

Notwithstanding its conclusion that the Convention did not require Ireland to allow divorce, the Court was clearly concerned about the impact of the lack of divorce on the child's legal situation "seen as a whole". ${ }^{38}$ In particular, it held that an examination of her situation revealed that it differed considerably from that of a legitimate child and that, without the means to eliminate or reduce these differences, the absence of an appropriate legal regime to reflect the third applicant's natural family ties amounted to a failure to respect her family life. ${ }^{39}$

Although the Court failed to find that the obligation to respect the family life of the adults required that they be placed in a position akin to that of a married couple, the ECtHR took the important step of recognising the impact of the child's legal status not just on her rights, but on those of her parents. In particular, it held that the "close and intimate relationship between the third applicant and her parents is such that there is of necessity also a resultant failure to respect the family life of each of the latter". 40 So, the absence of a legal regime reflecting the third applicant's natural family ties amounted to a failure to respect the family life of all three applicants, in violation of Article $8 .{ }^{41} \mathrm{In}$ adopting this approach, the Court demonstrated its awareness of the impact on private family relationships of the state's failure to grant them legal and public recognition. In this sense, Marckx and Johnston represented important milestones, since unmatched in standard setting, including in CRC jurisprudence, in the recognition at international level of relationships between parents and their children.

Moreover, the Court built on this case law in a number of cases about paternity beginning with Kroon v Netherlands in $1994 .{ }^{42}$ In this case, the applicants - again a child and

33 Johnston $v$ Ireland (1986) 9 EHRR 203, para.72. In doing so, the Court rejected that the principle established in the Marckx case applied only to mothers and children alone, finding that its principles were equally applicable to the instant case.

34 Ibid. para. 74.

35 Ibid. para 75. This reflects the approach of the Court according to which positive obligations vary in scope depending on the circumstances of each case.

36 Ibid. para. 45.

37 Ibid. para. 74.

38 Ibid. para. 75.

39 Ibid.

40 Ibid.

41 Ibid.

42 (1995) 19 EHRR 263. 
her parents - complained that the law operated so as to undermine their natural relationship, a situation which they considered in breach of Article 8. In particular, they complained that the irrebuttable presumption that the applicant's husband was the father of her child frustrated the child's father from being so recognised and thus breached all three applicants' Article 8 rights. The Court agreed and in, reaching this conclusion, it held that respect for family life requires:

that biological and social reality prevail over a legal presumption which, as in the present case, flies in the face of both established fact and the wishes of those concerned without actually benefiting anyone. ${ }^{43}$

This recognition by the Court that respect for family life under Article 8 requires legal recognition of social and biological ties represented a very important step in the application of the ECHR to the serious, practical issues affecting children and their parents in this area. The positive obligations approach was central to the Court's development of these principles. In particular, it demonstrated that the Convention does not simply require that the state refrain from interfering in families; rather, it established that how the national legal system governs and recognises family relationships - including in less traditional forms - is an issue that engages Convention rights, as well as being of huge importance to family members, including children. Again, here the ECtHR can be said to have gone further than the protection secured by the CRC although the Committee on the Rights of the Child has actively encouraged states parties to eliminate all discrimination between children on the basis of Article 2 of the CRC, which requires that all children enjoy Convention rights equally, regardless of their status (under Article 2(1)) or, notably, that of their parents (under Article 2(2)). ${ }^{44}$

It was perhaps a reasonable assumption from the Court's use of language ("social and biological ties") in Kroon that the Article 8 obligation to recognise family ties could only be invoked by those whose social and biological ties pointed to the same conclusion, i.e. where children lived socially with their biological parents. Indeed, to an extent this viewpoint informed the Court's judgment in the case of $X, Y$ and $Z \vee U K$ in $1996 .{ }^{45}$ This case concerned a female-to-male transsexual $(\mathrm{X})$, his partner $(\mathrm{Y})$ and their child $(\mathrm{Z})$ born by donor insemination (AID) who claimed that the failure to recognise $\mathrm{X}$ as the child's father on her birth certificate due to his status as a transsexual amounted to a failure to respect their rights under Article 8. Despite the somewhat unusual circumstances of the case, the Court applied the same approach as it had in other family ties cases. In this respect, its first conclusion was that the applicants enjoyed "family life" within the meaning of Article 8, and it then went on to consider whether the applicants' treatment showed the necessary "respect" for that family life. It began by citing the principles set out in the Marckx and Johnston cases, i.e. that where the existence of a family tie with a child has been established, the state must act in a manner calculated to enable that tie to be developed and legal safeguards must be established that render possible, from the moment of birth or as soon as practicable thereafter, the child's integration in his family. ${ }^{46}$ But, the Court then departed from its approach on the basis that this case concerned "different issues, since $Z$ was conceived by AID and is not related, in the biological sense, to X, who is a transsexual". ${ }^{47}$ Although it did not rule out that the state's positive obligation was engaged in this context,

43 (1995) 19 EHRR 263, para. 40.

44 See e.g. Committee on the Rights of the Child, General Guidelines Regarding the Form and Content of Initial Reports to be Submitted by States Parties under Article 44, Paragraph 1(a) of the Convention UN Doc. CRC/C/5 (1991).

$45 X, Y$ and $Z \mathrm{v}$ UK (1997) 24 EHRR 143.

46 Ibid. para. 43.

47 Ibid. 
it gave more careful consideration to the scope of that obligation. According to the Court, the facts of the case necessitated a different approach to previous cases, i.e. one that involved weighing up the arguments for and against the legal recognition sought by the applicants in order to strike a fair balance between "the competing interests of the individual and of the community as a whole". 48 With regard to the latter, the Court noted that there was a community interest in having a "coherent system of family law which places the best interests of the child at the forefront". 49 However, the Court did not articulate how protection of this "community interest" would be served by denying the parties recognition of the family life that had been found to exist between them. Especially problematic in this respect is the Court's finding that although recognising $\mathrm{X}$ as the child's father would not be harmful to her interests, it did not necessarily confer any advantage. ${ }^{50}$ In an apparent contradiction of earlier case law - including the Marckx, Johnston and Kroon cases - which had clearly identified the important advantages that flow from the legal recognition of family ties, the Court chose to downplay those advantages in the instant case, preferring instead to accentuate the measures that the applicants themselves could take to alleviate the difficulties they faced. For example, in respect of the issues of succession and legal recognition, the Court noted that their practical impact could be mitigated by $\mathrm{X}$ adopting a will and $\mathrm{X}$ and $\mathrm{Y}$ applying for a joint residence order, which would confer parental responsibility. While it accepted that it might be distressing for the child not to have her father's name on her birth certificate, it considered that the applicants were in a similar position to any other family where, for whatever reason, the person who performs the role of the child's "father" is not registered as such. ${ }^{51}$ With respect to the applicants' concerns about the effect on the child of the position, the Court noted that X was not prevented in any way from acting as the child's father in the social sense.

In further contrast to earlier jurisprudence where the ECtHR had displayed a clear understanding that children should not suffer the disadvantages conferred on them as a result of their parents' status, the Court in $X, Y$ and $Z$ appeared at best ambivalent about the impact of the failure to ensure respect for the child's family life. According to the Court, it was impossible to predict "the extent to which the absence of a legal connection between $\mathrm{X}$ and Z will affect the latter's development" and it went on to conclude that "there was no certainty as to how to best protect the best interests of the child in such cases". ${ }^{52}$ In conclusion, the Court held that "given that transsexuality raises complex scientific, legal, moral and social issues, in respect of which there is no generally shared approach among the Contracting States", Article 8 could not be taken to imply "an obligation . . . to recognise as the father of a child a person who is not the biological father". Accordingly, the fact that the law of England and Wales did not allow for legal recognition of the relationship between X and $\mathrm{Z}$ did not amount to a failure to respect family life within the meaning of Article 8.53

There are at least two significant features to this judgment. The first is the extent to which the Court was influenced by the absence of a European consensus in refusing to find that there was a positive obligation to recognise the right of a transsexual to have his name entered on the birth certificate of the child born to him and his partner. This is perhaps not surprising given that, at the time of the judgment, its other case law in this area also relied

$48 X, Y$ and $Z \mathrm{v} U K(1997) 24$ EHRR 143. para. 41.

49 Ibid. para. 47.

50 Ibid.

51 Ibid. para. 49.

52 Ibid. para. 51.

53 Ibid. paras 52-3. 
heavily on the lack of consensus that was seen to permeate the law affecting transsexuals. ${ }^{54}$ Related to this, however, is the second notable feature of the Court's judgment, i.e. that the Court clearly considered that the case concerned how the law should treat transsexuals, rather than how it should recognise children's family ties. In this way, for example, the Court's view that there are risks associated with recognising as the father of a child a person who is not the biological father was not made in the context of donor-supported assisted human reproduction - where such points could validly be made - but rather against the backdrop of the father's status as a transsexual. This is reinforced by the Court's summary dismissal of the disadvantages endured by the child concerned - whose family had no means available to alleviate these disadvantages - and its rather simplistic encouragement to her that she should not feel stigmatised by her legal status. In addition, the judgment made clear that notwithstanding that a relationship may constitute "family life", the Article 8 positive obligation to respect that family life applies only to those enjoying ties of a biological, as opposed to a social nature (although they can of course, and indeed may have to, enjoy both elements). ${ }^{55}$ Although the Court may have been able to draw support for its judgment in $X, Y$ and $Z$ from the lack of European consensus on the issue, the change in the Court's jurisprudence, signalled by Goodwin v UK in 2002,56 would suggest that this approach is now shaky at best.

Notwithstanding these weaknesses in the Court's approach, it is submitted that the Court can be commended for the concern it expressed in its judgment with regard to the best interests of the child. In particular, the Court questioned what the consequences might be of recording on the child's birth certificate the name of a person who was her social but not her biological father. Even if this was not the reason for the Court's decision, it reflects an apparent concern for the child's right to identity. Although this concern was more pronounced in later case law, it is regrettable that the Court did not take the opportunity in $\mathrm{X}, \mathrm{Y}$ and $\mathrm{Z}$ to articulate the child's right to identity with greater force and clarity. Drawing on the CRC would arguably have supported this approach.

As a result, it was 2002 before the child's right to identity emerged in ECHR case law, in the case of Mikulic v Croatia. ${ }^{57}$ Here, the applicant child complained that the state had failed to fulfil its positive obligation to respect her private life under Article 8 because she had been unable to ascertain the details of her identity. Under Croatian law, the only mechanism available to the applicant, who wished to establish her paternity, was to take a civil action against her putative father, JH. However, as nothing compelled him to undergo DNA testing, he refused to attend over a period of three-and-a-half years, after which time the first instance court relied on his non-attendance and the evidence of the child's mother to declare him the father. The appellate court overturned this decision having found this evidence to be inconclusive. When the case came to Strasbourg, the ECtHR acknowledged the importance to the applicant of obtaining accurate information about her identity and also accepted that states approach such situations in different ways. Nonetheless, it found that as there were no effective means to oblige JH to undergo DNA testing, this, together

54 For a review of these cases, and those that came later, altering the direction of Strasbourg law see U Kilkelly, "Article 8: the right to respect for private and family life, home and correspondence", in Harris et al., Law of the European Convention, n. 2 above, pp. 385-6.

55 E.g. the Court has yet to consider whether the relationship between a sperm donor and the child born as a result would enjoy family life. The former commissioner rejected this in G v Netherlands (1993) 16 EHRR CD 38.

56 Goodwin v UK (2002) 35 EHRR 447.

57 App. No 53176/99, 7 February 2002. 
with the absence of alternative means available to the applicant to establish her identity, resulted in a violation of Article 8. In conclusion, the Court noted that:

In determining an application to have paternity established, the courts are required to have regard to the basic principle of the child's interests. The Court finds that the procedure available does not strike a fair balance between the right of the applicant to have her uncertainty as to her personal identity eliminated without unnecessary delay and that of her supposed father not to undergo DNA tests, and considers that the protection of the interests involved is not proportionate. ${ }^{58}$

In other words, the inefficiency of the courts had left the applicant in a state of prolonged uncertainty as to her personal identity, which meant that the national authorities had failed to take the necessary steps to respect her private life. There is a welcome emphasis here on the measures that states must take to ensure effective protection of the applicant's private life, of which identity is an integral part. The Court was not perturbed by the applicant's status as a child and, indeed, made it clear that the child's best interest is an important factor in determining an application for the establishment of paternity. In doing so, the Court relied not only on the identity provisions of the CRC, but more generally on the requirement under Article 3, which requires that in all matters affecting the child the child's best interest must be considered as a primary consideration.

But the suggestion that Article 8 might require states to take steps to protect a child's right to identity was undermined somewhat by the decision of the Grand Chamber in Odière v France. ${ }^{59}$ This concerned the complaint by an adopted woman that the French law permitting anonymous adoption constituted a failure to respect her private and family life under Article 8. In particular, she complained that the fact that the legal system entitled her birth mother to veto her access to her identity constituted a violation of the positive obligation under Article 8. Weighing up the interests on both sides, the Court considered that a fair balance had been struck between the interests of the applicant who had a strong desire to know her true identity and that of her mother who clearly wished to remain anonymous. In light of the impact that disclosure would have on the mother, and the fact that the daughter had received certain non-identifying information about her, it considered that a fair balance had been struck in this case. The Court distinguished Mikulic on the basis that the instant case concerned two consenting adults (whereas the applicant in Mikulic was only five). So notwithstanding the Court's view (expressed in Gaskin v UK) ${ }^{60}$ that people "have a vital interest, protected by the Convention, in receiving the information necessary to know and to understand their childhood and early development", it found no violation in this case.

With some limited exceptions, therefore, it appears that Article 8 requires states to ensure that family ties that have both a biological and a social basis enjoy legal recognition. In establishing this position, the Court has expressed a strong awareness of the importance of legal recognition for family relationships, even if it has not applied this approach equally to all forms of family relationships. Although some exceptions are perhaps to be expected in what can be a sensitive area of national law and policy, it is regrettable that the Court has not always supported its conclusions with a well-reasoned analysis nor with a child-focused view of what is at stake for the applicants. In particular, in the cases of $X, Y$ and $Z$ and Odière the Court arguably relied too heavily on the absence of European-wide consensus

58 App. No 53176/99, 7 February 2002, para. 65.

59 (2003) 38 EHRR 871.

60 (1989) 12 EHRR 36. 
(which was debatable in both cases) and gave insufficient weight to the consequences for the individual child concerned of the situation complained of as well as the importance of the right (to identity) being invoked. At the same time, however, the ECtHR, through this body of case law, has made an important contribution to standard setting in the area of the recognition of legal relationships, on whose foundations a new Council of Europe instrument will be based. It is patently clear that the positive obligations approach has been central to the articulation of state obligations under Article 8, and in respect of putting flesh on the bones of the child's right to identity it can also be said to have gone further than the $\mathrm{CRC}$ in this area.

\section{Promoting family life}

A second area of family life jurisprudence that has been underpinned by the positive obligations approach is the ECHR case law with regard to protecting the integrity of family life relationships. Here too, the Court has made a unique and important contribution to children's rights standards with an emphasis on ensuring that steps are taken to promote the effective realisation of rights. The Court's approach was first established in the context of public care, where parents whose children were placed in care complained about their inability to have their children returned to them. In a long and steady line of such cases, the Court has consistently held that Article 8 includes a right for parents to have measures taken with a view to them being reunited with their children and an obligation for the national authorities to take such action. ${ }^{61}$ Significantly, however, the Court went on to apply these principles to the private family law context and, in doing so, the ECtHR used the positive obligations approach to strengthen the effective protection associated with the right to respect for family life under Article 8. In the seminal case of Hokkanen v Finland, the applicant's children had been placed, with agreement, in the custody of his parents after his wife's death. ${ }^{62}$ As time went on, however, they refused to return the children to him and also sought to deprive him of contact with them. The situation was unresolved for such a long time that the Finnish courts ultimately agreed to transfer legal custody of the children from their father to their grandparents.

Before the ECtHR, the applicant complained that this constituted a failure to respect his family life with his children. Considering the matter under Article 8, the Court agreed that the provision imposed a positive obligation on the state to take measures to facilitate the reunion of parent and child even in the private context. However, it went on to note that this obligation was not absolute, "since the reunion of a parent with a child who has lived for some time with other persons may not be able to take place immediately and may require preparatory measures being taken to this effect". ${ }^{63}$ According to the Court, "the nature and extent of such preparation will depend on the circumstances of each case, but the understanding and co-operation of all concerned will always be an important ingredient". ${ }^{64}$ Moreover, whilst national authorities must take every effort to facilitate co-operation:

any obligation to apply coercion in this area must be limited since the interests as well as the rights and freedoms of all concerned must be taken into account, and more particularly the best interests of the child and his or her rights under Article 8 of the Convention. ${ }^{65}$

61 See Eriksson v Sweden (1989) 12 EHRR 183, para. 71; Margareta and Roger Andersson v Sweden (1992) 14 EHRR 615, para. 91 and Olsson v Sweden (No 2) (1992) 17 EHRR 134, para. 90.

62 (1994) 19 EHRR 139.

63 Ibid. para. 62

64 Ibid.

65 Ibid. 
Where contacts with the parent might appear to threaten those interests or interfere with those rights, it is for the national authorities to strike a fair balance between them. Ultimately, what was decisive under Article 8 was whether the national authorities had taken "all necessary steps to facilitate reunion as can reasonably be demanded in the special circumstances of each case". ${ }^{66}$ In this case, although the Court acknowledged that there were difficulties arranging contact as a result of the animosity between the parties, it rejected that the government could not be held liable for the obstacles created by the children's grandparents. Because the inaction of the authorities placed a burden on the applicant to have "constant recourse to a succession of time-consuming and ultimately ineffectual remedies to enforce his rights", his right to respect for family life under Article 8 had been violated. ${ }^{67}$

This judgment has since been followed by a long list of cases wherein the Court has applied these principles to the specific context of child abduction, a growing and complex international problem where children are removed from one jurisdiction without the permission of the custodial parent. Given that, numerous international instruments and measures have been adopted in the area of child abduction, it is submitted that the ECtHR has made a unique contribution to this area. ${ }^{68}$ The case of Ignacollo-Zenide $\mathrm{v}$ Romania ${ }^{69}$ illustrates the Court's approach effectively. This concerned a mother who sought to have her children returned to her custody following their abduction to Romania by their father. The ineffectiveness of the authorities' response led her to complain to the ECtHR in respect of a breach of her family life rights under Article 8. According to the Court, the efforts of the Romanian authorities to secure implementation of the court order to return the children to the applicant were indeed inadequate and ineffective. The fact that the father's failure to return the children to their mother had no consequences for him, combined with the authorities' failure to take sufficient steps, including the arrangement of preparatory contact to reunite them, led to a violation of her rights under Article 8. Importantly, not only had the state authorities failed to take the necessary measures to facilitate reunion (and respect for family life), they had failed to do so within a reasonable time.

As in Hokkanen, the Court acknowledged in Ignacollo-Zenide that the duty to take action to bring about the reunification of the abducted children and their custodial parent was not absolute and would depend on the circumstances. According to the Court:

any obligation to apply coercion in this area must be limited since the interests as well as the rights and freedoms of all concerned must be taken into account, and more particularly the best interests of the child and his or her rights under Article 8 of the Convention. Where contacts with the parent might appear to threaten those interests or interfere with those rights, it is for the national authorities to strike a fair balance between them. ${ }^{70}$

Although the ECtHR did not refer expressly to the CRC, its judgment is clearly informed by CRC principles, notably Article 3 (the best interests principle) and Articles 9 and 10 dealing with the separation of children from their parents. The uniqueness of the ECtHR's contribution in this area is also apparent from its opinion that in such cases, "the adequacy of a measure (to reunite parents with their children) is to be judged by the swiftness of its

66 (1994) 19 EHRR 139.

67 Ibid. para. 61.

68 See N Lowe, M Everall and M Nicholls, The International Movement of Children (Bristol: Family Law 2004) and U Kilkelly, Children's Rights in Ireland: Law, policy and practice (Dublin: Bloomsbury Publishing 2008), pp. 167-99, for details of the range of instruments that now make up international child abduction law. See also J Murphy, International Dimensions in Family Law (Manchester: Manchester University Press 2005).

69 Ignaccolo-Zenide v Romania (2001) 31 EHRR 7.

70 Ibid. para. 94. 
implementation". ${ }^{71}$ According to the Court, this is due to the fact that the passage of time can have irremediable consequences for relations between the child and the parent who does not live with him/her. Significantly, in this context, the Court has referred to the requirement of expedition given expression in Article 11 of the Hague Convention on Child Abduction. ${ }^{72}$ Accordingly, in Ignacollo-Zenide, and in many subsequent cases, the Court has held not only that the authorities had failed to take all the measures that could reasonably be expected to reunite parent and child, but that they did not do so "without delay". 73

This illustrates that one of the innovative aspects of the case law in this area is the interplay in ECHR case law between the duty on the state to respect family life under Article 8 of the ECHR and state party compliance with the requirements of the Hague Convention on Child Abduction. In particular, the Court has sometimes been drawn into assessing whether state parties to the ECHR are complying with their Hague obligations. For example, in Ignacollo-Zenide, the Court referred to Article 7 of the Hague Convention (which sets out the duties on Convention states with respect to securing the prompt return of an abducted child) in the context of assessing compliance with Article 8 of the ECHR. ${ }^{74}$ Moreover, in Bajrami v Albania the Court went even further in finding that its judgment that a violation of Article 8 had been found (on the basis of the ineffective measures taken to reunite a parent with an abducted child) was related to the absence of measures designed to remedy Albania's failure to ratify the Hague Convention. ${ }^{75}$ Albania lacked the legal framework to ensure the practical and effective protection of the applicants' family life that is required by the state's positive obligation enshrined in Article 8 of the ECHR.

The CRC recognises the importance to children of family relationships in a number of contexts including where children are separated from their parents. ${ }^{76}$ Similar to the right to identity discussed above, ECHR law has put flesh on the bones of these principles by incorporating into the duty to respect family life under Article 8 important positive and practical obligations, which are designed to promote the integrity of the child's family relationships and to realise the child's right to enjoy contact with his or her parents unless that is contrary to the child's best interest. Although the ECtHR has made little use of the $\mathrm{CRC}$ in this context, its judgments are clearly consistent with CRC principles. Moreover, its use of the arguably more relevant Hague Convention has given further force to its case law while at the same time giving additional teeth, through the ECHR system, to the Hague Convention itself. Again, here the ECtHR has applied its positive obligations approach in a manner that is not only consistent with international children's rights standards but in a way that has built upon them.

\section{Respect for physical integrity}

The third area of ECHR jurisprudence in which the positive obligations is worthy of analysis is in relation to the child's right to physical integrity. The child's right to protection

71 Ignaccolo-Zenide v Romania (2001) 31 EHRR 7, para. 102.

72 Convention of 25 October 1980 on the Civil Aspects of International Child Abduction. See also Karadzic v Croatia App. No 35030/04, 15 December 2005.

73 See Sylvester v Austria (2003) 37 EHRR 417. See also Maire v Portugal (2006) 43 EHRR 23, where the Court was critical of the four-year delay in returning the child, who was particularly young at the time.

74 Ignaccolo-Zenide v Romania (2001) 31 EHRR 7, para. 113.

75 See Iosub Caras v Romania [2007] 1 FLR 661 and Monory v Hungary and Romania (2005) 41 EHRR 771.

76 See, in particular, Article 7, which refers to the child's right to know and be cared for by his/her parents, and Article 9, which provides for the child's right to maintain contact with both parents unless this is contrary to the child's best interests. Furthermore, Article 10 makes provision for the reunification with their parent of children who are separated from them across borders. 
from harm has strong support in Article 19 of the CRC, which requires states to take all necessary measures to protect children from all forms of harm, abuse and neglect, including at the hands of their parents and carers. This duty to protect children has been elaborated in the Secretary General's Study on Violence against Children, which led inter alia to the appointment in 2009 of the first United Nations Special Representative on Violence against Children and numerous supporting international instruments. ${ }^{77}$ The ECHR makes no reference to children's right to protection from violence but this has not prevented applicants from invoking ECHR provisions in respect of children's treatment both at the hands of the state and of their carers. In 1987, the ECtHR was asked to consider an application concerning a child's right to respect for physical integrity, as an integral part of respect for her private life under Article 8 of the ECHR. In $X$ and $Y \mathrm{v}$ Netherlands in 1987, the Court first recognised that the state's duty to respect private life may require it to take positive action to intervene in relations between individuals. ${ }^{78}$ The facts of the case were that there had been a sexual assault on a 16-year-old girl with an intellectual disability by an adult male. Due to a lacuna in Dutch law at the time, she was deprived of a remedy because it was not possible to have the alleged perpetrator prosecuted (without her making a complaint which she lacked the capacity to do). She complained that this amounted to a failure to respect her physical integrity, which formed part of her private life, which the state was required to respect under Article 8. Considering the merits of the case, the Court accepted that physical integrity formed a part of a person's private life, and it went on then to articulate a strong view of what the positive obligation to respect physical integrity means in this context. ${ }^{79}$ In particular, the Court expressed the view that, in the circumstances of the case, the absence of an effective criminal remedy constituted a failure to respect the girl's private life which required measures of effective deterrence. Importantly, civil remedies, which might otherwise be effective, were insufficient to protect her Convention interests because they were not without their practical drawbacks. Due to the "fundamental values and essential aspects of private life . . . at stake" here, effective deterrence, which the Court considered to be "indispensable in this area", could only be achieved by criminal law provisions. ${ }^{80}$

The strength of the Court's conclusion - that violence against children required measures of deterrent supported only by criminal remedies - was not matched in later cases. In particular, in the case of Costello-Roberts v UK, the Court rejected that Article 8 could support a positive obligation to respect the physical integrity of a child (as part of his/her private life). ${ }^{81}$ This concerned a boy attending a private school who received three whacks on his bottom with a gym shoe as a punishment for ill-discipline. The applicant complained that this was a breach of his physical integrity under Article 8 of the Convention. This was rejected by the Court, which held that the treatment did not entail sufficiently adverse effects for the applicant's physical or moral integrity to found a violation of that provision. The Court undertook its more substantive analysis of the complaint under Article 3, however, signalling a clear preference, borne out in subsequent case law, for the consideration of complaints of violence against children under that provision. ${ }^{82}$ Despite

77 The UN Secretary General's Study on Violence against Children, 2006, available at www.violencestudy.org. Ms Marta Santos Pais is the current office holder. See also Committee on the Rights of the Child, General Comment No 8, n. 8 above; and the Council of Europe Policy Guidelines on Integrated National Strategies for the Protection of Children from Violence, Recommendation CM/Rec. (2009)10.

79 Ibid. para. 22.

80 Ibid. para. 27.

81 Av UK (1993) 19 EHRR 112.

82 E.g. in $Z \mathrm{v} U K$, the Court considered the ill-treatment of the applicant children under Article 3, finding no separate issue to arise under Article 8. See further below. 
the failure of the merits of the applicant's complaint - a majority of five (from nine) judges found that his treatment was not severe enough to raise an issue of inhuman and degrading treatment under Article $3^{83}$ - the Costello-Roberts case made it clear that ECHR obligations cannot be delegated to private institutions like schools and that they apply, equally, in the private as well as the public sphere. This principle took on even greater significance in the case of $A \mathrm{v} U K$ in $1993,{ }^{84}$ which concerned the caning of a nine-year-old boy by his stepfather. His injuries were considered to be sufficiently serious to merit the initiation of criminal proceedings against the boy's stepfather, who was acquitted on the defence that the punishment amounted to "moderate and reasonable chastisement". The boy complained that this represented evidence that the legal framework in place in England and Wales failed to provide him with effective protection from inhuman and degrading treatment contrary to the Convention. The positive obligations approach was key in the Court's response. in particular, in its judgment, the Court set out the positive obligations under Article 3 of the Convention by reading it together with the duty under Article 1 of the ECHR to "secure" Convention rights to everyone. On this basis, the Court ruled that the Article 1 obligation requires states "to take measures designed to ensure that individuals within their jurisdiction are not subjected to treatment proscribed by Article 3, including such treatment administered by private individuals". Moreover, the Court went on to find that "children and other vulnerable individuals are entitled to protection in the form of effective deterrence against such serious breaches of personal integrity". Applying this approach, the Court held that the UK had infringed Article 3 because its law did not adequately protect a child against the infliction by a parent of suffering that reached the threshold of Article 3. Accordingly, the Court's conclusion was that the law and its application did not provide the boy with effective protection from ill-treatment. Thus, it was the way in which the legal framework was organised that was problematic and the state's responsibility for this meant that a violation of Article 3 was the result. The fact that this mirrored the earlier observation of the Committee on the Rights of the Child, which in 1995 had queried the compatibility with the CRC of the defence of moderate and reasonable chastisement, ${ }^{85}$ serves to reinforce the link between both conventions, notwithstanding the difference in their provision.

Significantly, the Court went even further in its application of the positive obligations approach under Article 3 in $Z_{\mathrm{v}} U K .{ }^{86}$ Here, a family of four children had suffered appalling abuse and neglect at the hands of their parents and, despite their involvement with the family, social services had failed to intervene in time to prevent them from permanent damage. Having found that their neglect and injury reached the level of severity required to bring it within the scope of Article 3, the ECtHR went on to note that the local authority was aware of this treatment and had both a statutory duty and a range of powers available to it to protect the children. Despite the sensitive and difficult decisions facing social services and the important countervailing principle of respecting and preserving family life, the Court concluded that the system had failed to protect the children from serious, longterm neglect and abuse in violation of Article $3 .{ }^{87}$ In terms of its approach, the Court

83 Contrast this with Warwick v UK, where the (former) European Commission of Human Rights found that one stroke of a cane given to a 16-year-old girl constituted degrading punishment in violation of Article 3: App. No 9471/81, 60 DR 60, p. 5, paras 86-8.

84 (1993) 19 EHRR 112. See R Smith, "To smack or not to smack? A review of $A \mathrm{v} U K$ in an international and European context and its potential impact on parental physical chastisement" (1999) Web Journal of Current Legal Issues.

85 Committee on the Rights of the Child, Concluding Observations: United Kingdom of Great Britain and Northern Ireland CRC/C/15/Add.34, 15 February 1995, para. 16.

86 (2000) 34 EHRR 97.

87 Ibid. paras 69-75. 
followed the reasoning applied in $A \mathrm{v} U K$ finding that Article 1 of the ECHR taken together with Article 3 requires states to take measures designed to ensure that individuals within their jurisdiction are not subjected to torture or inhuman or degrading treatment, including such ill-treatment administered by private individuals. It went on to say that such measures should provide "effective protection, in particular, of children and other vulnerable persons and include reasonable steps to prevent ill-treatment of which the authorities had or ought to have had knowledge". 88

$Z_{\mathrm{v}} U K$ is an important case for a number of reasons. First, it establishes without doubt that Article 3 applies to treatment suffered by children at the hands of their carers. Second, it offers the first child-focused analysis under the ECHR of where the balance should fall between respecting the integrity of the family and protecting children from abuse. Although it is difficult to identify the exact nature of the positive obligation that Article 3 imposes on states in the area of child protection, nonetheless it sets down an important benchmark that child protection services must be proactive in identifying and responding to signs that children are suffering physical and psychological harm that, with the lapse of time, may cause long-term, even permanent problems. ${ }^{89}$ Indications from the judgment are that respect for the child's right to protection from harm under Article 3 requires timely intervention in the family, with effective and practical steps to be taken when the situation at home does not show a significant and timely improvement. As in the other areas discussed above, the contribution of the ECHR to the child's right to protection from harm represents a practical, important and original contribution to this area. Building on Article 19 CRC, the ECtHR's positive obligations jurisprudence on Article 3 is an important and welcome addition to international law on the child's right to protection from harm.

\section{Conclusions}

The contribution of the ECHR to children's rights law is often underplayed or ignored when contrasted with the contribution of the CRC. Yet, as has been highlighted here, the application of the ECHR to children's cases in several important areas has led to the development of positive obligations, notably under Articles 3 and 8 of the ECHR, which both develop existing children's rights standards and articulate an entirely unique set of legal requirements. In this way, the ECtHR has not only developed children's rights jurisprudence that builds on the CRC, it has also forged a new path for children's rights in the areas discussed here. Although the focus on practical and effective mechanisms to realise ECHR rights has played an important role, this article demonstrates the significant contribution made by the positive obligations approach in all three areas considered, i.e. family ties, family reunification following abduction, and child protection. In each case, it is notable that the positive obligations approach defines in practical detail what states must do to ensure effective respect for ECHR rights and, although this approach has wavered from time to time, the case law is largely coherent and consistent.

Given that the ECtHR's approach to children's cases has been somewhat unpredictable to date, it is difficult to foresee where the scope of the positive obligations may next be realised. Each case is genuinely decided on its merits and is dependent on the set of circumstances that bring each child applicant to Strasbourg. Nonetheless, challenges to the child's right to identity associated with assisted human reproduction and with adoption would seem inevitable and here a positive obligations approach that seeks to respect the child's rights to identity in line with the CRC would bring added value to existing standards.

88 (2000) 34 EHRR 97, para. 73.

89 See the Report of the European Commission of Human Rights in $Z_{\mathrm{v}}$ UK App. No 29392/95, Comm. Rep., 10 September 1999, para. 97. 
The pressure to extend Article 8 case law to require states to give legal recognition to less traditional family forms - notably those headed by same-sex parents - is arguably growing, especially where children are affected. Similarly, the Court's failure to establish more robust obligations to ensure respect for father's rights under Article 8 could come under scrutiny as family breakdown continues and awareness about the importance of contact with both parents builds. In this regard, the Council of Europe Convention concerning Contact ${ }^{90}$ may provide some support for the development of an obligation upon states to do more in this area. With respect to child protection, the development of greater consensus around the measures necessary to protect children from violence should support the development of more onerous positive obligations on states under Article 3, and the elimination of physical punishment may well emerge again before the Court in this context. Overall, as the case law demonstrates, the ECtHR is not only capable of developing new standards of human rights protection from a child's perspective, it is equally willing to build on those that currently exist, under the CRC and companion instruments. 
